INDEPENDENT JOURNAL OF MANAGEMENT \& PRODUCTION (IJM\&P)

http://www.ijmp.jor.br

v. 12, n. 4, May-June 2021

ISSN: 2236-269X

DOI: 10.14807/ijmp.v12i4.1358

\title{
FACTORS THAT INFLUENCE THE PURCHASING BEHAVIOR OF THE CONSUMER OF NATURAL PRODUCTS
}

\author{
Rhubens Ewald Moura Ribeiro \\ Centro Universitário Santo Agostinho (UNIFSA), Brazil \\ E-mail: rhubens.ribeiro@gmail.com \\ Pedro Henrique de Sousa Oliveira \\ Centro Universitário Santo Agostinho (UNIFSA), Brazil \\ E-mail:phenrique_adm@outlook.com \\ Kaíque Barbosa de Moura \\ Centro Universitário Santo Agostinho (UNIFSA), Brazil \\ E-mail: kaique.96moura@gmail.com \\ Cecília Rochele Silva de Abreu \\ Centro Universitário Santo Agostinho (UNIFSA), Brazil \\ E-mail: ceciliarochelepi@hotmail.com \\ Carlos Alberto de Sousa Ribeiro Filho \\ Universidade Federal do Piauí (UFPI), Brazil \\ E-mail: carlosribeiro@email.com \\ Luis Fernando Silva Monteiro \\ Centro Universitário Santo Agostinho (UNIFSA), Brazil \\ E-mail: luissfernanndo@hotmail.com \\ Denise Juliana Bezerra de Pontes Barbosa \\ Universidade Federal do Piauí (UFPI), Brazil \\ E-mail:denisejbpontes@hotmail.com
}

Submission: 6/4/2020

Revision: $7 / 3 / 2020$

Accept: 8/12/2020

\section{ABSTRACT}

The consumption of natural products has become increasingly intense in recent years, arousing the interest of several new entrepreneurs and companies that already operate in the market, whether with the same type of business or not, as within this area other issues are inserted that are of collective interest. The study of consumer behavior comprises the actions of purchase, use and disposal of the purchased product and, also, the processes and decisions that occur before and after these actions. Therefore, the objective of this article is to identify which and how certain factors may influence the behavior of consumers of natural products in their purchase decision process. 
DOI: $10.14807 /$ ijmp.v12i4.1358

The methodology used was the bibliographic research analyzing several and relevant references on the theme. The results of this research show that in order to be successful in the field of natural products, it is essential to improve the relationship between organization and consumer and how important it is to know all the aspects that involve their decision and behavior, since the consumer buying behavior of natural products it is not only based on your personality, but also on personal, cultural, emotional, psychological factors and also on environmental issues. The survey also details the importance of consuming natural products for society and the environment, providing a healthier environment for those involved. Thus, the work emphasizes the relevance of knowledge and investment in marketing and research that can help companies to dedicate themselves more to attract consumers not only in their area of activity, but also consumers of other products and / or services, winning and retaining new customers.

Keywords: Consumer behavior; Natural products; Marketing; Consumer profile

\section{INTRODUCTION}

This work seeks to show which and how certain factors may influence the behavior of consumer of natural products in their purchase decision process. It reveals the importance of analyzing these factors and the profile of this kind of consumer for the company, so it can deal properly with this issue that is receiving greater visibility and acceptance by consumer and organizations that work with this kind of business. Before that, it is necessary to comment a bit about the marketing field, which is important for a better understanding (Ono et al, 2014; Peter \& Olson, 2010).

Marketing deals with satisfaction of consumer's needs and desires, generating profit for who does it, employing several tools and techniques to make the best out of the market, at the lower possible cost to the organization; achieving previously defined goals. With it, one can develop strategies of good relationship and connection with consumers through projects, websites, researches, advertisements and other ways of conquering consumer (Kotler \& Keller, 2012).

Another detail to be emphasized, of no lesser importance, is that marketing also involves both parts of a transaction in a deal, that is, buyer and seller alike use it to, directly or indirectly satisfy their needs, respectively, of sale or purchase (Cobra \& Brezzo, 2010). 
DOI: 10.14807/ijmp.v12i4.1358

Human being has always sought to satisfy his needs, whatever they may be, so it is of utter importance to evaluate how the consumer behaves in relation to the purchase of products or services and which factors influence this behavior, it is necessary to know them and what they want, how they want it and even the opposite of that, in order to define a basis of purchase behavior on which the manager can find support to serve them in a precise and smart way and thus generate profits for the organization (Medeiros \& Cruz, 2006).

For this to happen, the manager must know who his consumers are, he must seek to understand what and how they will buy; in other words, he must try to understand their purchase behavior. Each individual has their own preferences and opinions about what surrounds them. However, nonetheless this seeming individuality, there are influences acquired along a lifetime whether with those closest to us or even with those around us and the surroundings in which we live (Kotler \& Keller, 2012; Natel, Tarcia \& Sigulen, 2013).

When it comes to the market of natural products, we are referring to a steadily growing market, which has become more and more valued thanks to the search of its consumer for products that offer a better and greater quality of life for him and those around him. Therefore, another kind of consumer emerges, influenced by a wider set of values, social and personal processes, not to mention cultural ones. Given that consumption of natural products encompasses the search for healthy products practically free of any kind of artificial ingredients, this is also caused by growing awareness of men to what mankind has been causing to the environment, such as pollution, greenhouse effect etc. (Rossini, 2016).

Three factors may affect consumer's purchase behavior: cultural, personal and social; these factors shape consumer's buying behavior rendering him more demanding and insightful on regard to the product he wishes to acquire. Therefore, as already mentioned, studying these factors grants us a more precise notion of the kind of consumer we are dealing with, in terms of his financial capacity, manners, wishes, etc. rendering him more lean to believe in the quality of services, client support, and in the company as a whole in terms of the fulfillment of his wishes and needs, gaining his loyalty and gathering the organization more and more prestige and esteem (Teixeira, 2010).

Therefore, this paper's goal is to describe how the influence of social, personal and cultural factors works on buying behavior of the consumer of natural products. It is believed that this work may bring to the organizations of this branch of business a greater awareness of the relationship they must sustain with their consumers so that they can be more successful on 
DOI: $10.14807 /$ ijmp.v12i4.1358

the future; in addition to showing the importance of consuming natural products for society and the environment, providing a healthier environment for those involved.

At first, this paper contextualizes one of the main ways of obtaining important and significant information about the green consumer, which is an essential factor for the assistance of companies that operate in this segment, as well as those that are entering this market. Right after, we search to approach the main factors that influence the consumer in the act of buying, besides deepening further on the profile of the consumer of natural products, seeking to assess his main characteristics. Finally, at the conclusions, we highlight the social, economic and personal importance, as well as other fields encompassed by the environmental issue, besides, of course, demonstrating how the buying behavior of the consumer of natural products must be addressed by organizations to assure greater support in their strategies.

\section{THE ORETICAL FRAMEWORK}

This section presents the theoretical aspects concerning the research theme, explaining concepts related to marketing and consumer's behavior.

\subsection{Marketing}

It is well-known that society is undergoing many transformations. New expectations and needs arises followed by wishes, new values are born every day, continuously reducing control of people and organizations. An organization functions as living, interdependent system, bearing values, mission and specific goals. Each part of this system works in harmony with the others in order to be successful in carrying out business processes. However, thanks to marketing, which is constantly evolving, techniques can developed to meet these transformations (Basta, 2015).

But how marketing work in organizations? In face of countless transformations taking place in an increasingly competitive economic scenario, it is proven that companies cannot abandon marketing researches at no time. Marketing research has as its main function to develop techniques through collected information that are employed to identify and define marketing problems related to clients wishes and needs (Malhotra, 2012).

\subsection{Consumers Behavior}

Studying the individual in relation to his wants, desires and needs is a fundamental step to understand his behavior. Besides that, the individual's social relations, culture and further attributes leads us to a more detailed regard of his behavior in order to evaluate his decision of 
DOI: 10.14807/ijmp.v12i4.1358

buying a certain product; evaluating his emotions, motivations and sensations is of utter importance to reach a level of relationship that satisfies the client in the best possible way, conquering him (Pinheiro et al., 2011; Portela, 2011).

Various fields of knowledge such as economy, sociology etc., also addresses the individual trying to develop their own concepts that will drive them to become more demanding and critical, whatever their interests may be. This undoubtedly affects his relationship with the seller, who should also use the same tools in order to guarantee a better assistance for his client (Lazzari et al., 2012).

Anyway, there is no doubt that the process between seller and consumer involves the most diverse strategies and concepts, which will benefit both sides, as one will acknowledge de other, that is, there will be a relationship of trust because one know how to deal with the other, that is client and salesman alike know each other and seek to fulfill their needs based on the other, driving the study of this relation to an even more complex level, since it includes and attributes more weight to the variations of market behavior of companies, individuals, society, and everyone involved in the relationship company-consumer. With that, the marketing professional becomes of fundamental importance, as this field also encompasses the study of these relationships (Pinheiro et al, 2011).

Nowadays companies have a more attentive look to its consumer, what raises the level of competition between them, each one with its strategies and concepts that very often bring benefits to consumers and society as well, given the creation of more jobs, offers, promotions etc. that heats and enriches the market (Larentis, 2012).

Much has been discussed about how important is for the seller to know the one who buys his product, the consumer. But what consumers behavior means? Consumers behavior comprises the act of buying, using and disposal of the acquired products as long as processes and decisions that occurs before and after these actions. Aiming to understand how this behavior works, several studies were carried and one can notice that many consumers associated buying of theirs products to their families or to the people who also used those products as well as other factors (Zuppani \& Lima, 2014).

Human being is influenced every day, in the most diverse ways, whether by family, friends, mass medias or by himself, to buy, think, act etc., this capacity of the human being to influence and be influenced deserve close attention from the manager, since he can use these influences to base the decision of pricing, placing of sale, type of product, promotion, and 
INDEPENDENT JOURNAL OF MANAGEMENT \& PRODUCTION (IJM\&P)

http://www.ijmp.jor.br

v. 12, n. 4, May-June 2021

ISSN: 2236-269X

DOI: 10.14807/ijmp.v12i4.1358

several other marketing strategies to be successful in selling his products. He will know that, for example, selling a product that relieves that sensation will bring him good profits; creating attractive and far-reaching promotions will spark customers interest and bring them to his store. However, the manager also know that he may not be the only one to be aware of this kind of strategies in that market (Vilas Boas, 2005).

Competition, as previously mentioned, may bring good results for customers because companies struggle to grasp that market, being led to create new strategies, invest in technologies, invent promotions etc., increasing the movement of the market. Nonetheless, those stratagems would be useless if the client remains unknown. This is where consumer behavior comes into play as success factor to the company who knows how to work with it. A well done study of the market, of its more remarkable aspects, its consumers, how they behave, why they buy that product or stop buying it etc. will bring the necessary information for the company to define its sales plan in a way that consumer may be reached in his most detailed aspects and, therefore, retain him closer and closer (Oliveira, Gonçalves \& Paula, 2011).

Therefore, Marketing is of significant importance for any company, since with good policies, strategies of advertising, promotions, prices, deadlines etc., the company can create greater value for its client. Since a long time, around the 1960`s, Marketing is evolving in such a manner that old concepts which regarded it as a simple activity capable of attracting clients has gained a broader and more detailed sense as attracting clients by means of a pool of strategies entirely coordinated and organized for selling a product and satisfying both parts of a transaction. All of this thanks to the evolution of consumer behavior that, previously could be easily influenced by others consumers and simply accept it, and now starts to question his decisions and to act in such a systematic and organized way that it becomes the main challenge of nowadays manager (Gomes \& Kury, 2013).

Companies finally understood the necessity of reaching out to the consumer, experience his day-to-day live, understand how he works, know what, when, how, where and why he wants that product. To this end, they must also know the factors that affects their buying behavior, such as social, personal, psychological and cultural factors. What is his origins and influences in face of the consumer and how it affects him (Freire, Lima \& Leite, 2009).

\subsection{Factors that Affect Consumer Behavior}

Nowadays companies have a great challenge to face, namely the conquest of its consumer. They need to understand how consumers behave and what factors influence that 
INDEPENDENT JOURNAL OF MANAGEMENT \& PRODUCTION (IJM\&P)

http://www.ijmp.jor.br

v. 12, n. 4, May-June 2021

ISSN: 2236-269X

DOI: 10.14807/ijmp.v12i4.1358

behavior. Among several factors that might interfere on purchase decision there are four that stands out: social, psychological, cultural and personal, and one of them, the psychological factor, presents a strong influence on purchase decision by the consumer (Aquino, 2007).

\section{Social Factors}

Human being is a social being. There are several influences that society may have on purchase-decisions of an individual, among them the reference groups, his family, social role and status are some of the most important (Ramos et al, 2013).

Individuals, when in a group, are lean to acquire some features of the environment in relation to his purchase. Very often, he uses comparisons, values and further aspects involved in the relation of that group with him. These features of reference groups become decisive when compared to other kinds of influences, as they are closely related to the individual's daily routine. (Correa, 2012).

The family, group of greater influence and reference, is beyond a simple relationship because it entails feelings, options, desires; it involves the consumer like no other. The manager who seizes knowledge about this kind of group will find great success on influencing his consumer since will be dealing with his most innermost being; if he knows how to do a good work with this aspect he will get a relation of closeness with the consumer, as it was seen in several other cases of client fidelity to the company, and that will bring benefits such as comfort, trust, so that consumer will feel good and keep getting back to the company (Matteil, Machado \& Oliveira, 2006; Oliveira \& Neto, 2016).

The question regarding status and role occupied by a person in society is also an important factor for the definition of how the consumer buys the product, as he may drive his interest for that product based on information's he obtained from social groups in which he was inserted, he may want to acquire the same products etc., everything for being more integrated to the social group, for personal reasons, for example (Vilain \& Pereira, 2013).

\subsection{Psychological Factors}

Many are the psychological factors that may influence an individual's purchase decision, need and desire, for example, are also very important. Human being has needs that he disposes in importance levels, often excluding or adding to his desires, and that determines, in a way, which kind of product he may show more or less interest in (Caro, 2005, 2010). 
DOI: 10.14807/ijmp.v12i4.1358

The main psychological factors examined were: motivation, perception, learning and emotion.

\subsection{Motivation}

Motivation is considered as a force that impels the behavior of the individual, for example, for a certain goal. It comes from a need, desire or want of the individual for achieving a given goal, of getting what he wants. With this, some scholars have developed theories to analyze the behavior of the individual in its relations with motivation, among them Maslow, Herzberg and Freud (Figueiredo, 2012).

\subsection{Perception}

Perception is the process by which people systematize their ideas about the world. They affect the consumer internally, in a real way, being of such importance to behavior analysis. This perception directly links external and internal aspects of the individual, leading him to maintain several opinions about, for instance, product's sale, if the salesperson is being too pushy in the way he talks, or even of what the product represents to society (Torres, 2007).

\subsection{Emotion}

Consumer doesn't only buys based on reason, he is often emotionally influenced to buy, be it the brand or product, the use of advertisements, images and videos have major influence on consumer's purchase decision, he feels obstinate, determined to a cause, to be able to contribute with that etc., that is, inspirations that influences his innermost and will drive him to buy the product more certainly (Dorneles et al., 2015).

\subsection{Learning}

Learning is the achievement of absorbing that which we get in touch with, gaining experience and knowledge about it. Therefore, any kind of product that the client had contact with and came across with its characteristics, would him have a decision about the purchase, that is, to say, if the product of a specific brand is good for him, in the next purchase he may choose for the same product or a similar product of the same brand (Porto \& Oliveira-Castro, 2013).

\subsection{Cultural Factors}

Many consumers associate their consumption of products and/or services to a representation of theirs cultural habits, in other words buying specific products or services doesn't means just buying, it also means to be part of a cultural model which is being followed, 
DOI: $10.14807 /$ ijmp.v12i4.1358

in other words, the product passes from something only material to something with symbolical value to the followers of that culture, making them adopt such a product or service as indispensable to their way of life (Pena, Coutinho \& Pépece, 2012).

The set of beliefs, rituals, customs and other values constitute the culture of a society. These are broadly integrated in the individual's behavior, influencing his process of purchase decision. The diversity of cultures on the globe render the identification of consumer's purchase behavior increasingly broad. Manager must seek ways to identify how this factor may influence his consumer through field research, studies based on projections, observations etc (Watanabe, 2014).

\subsection{Personal Factors}

Aspects such as age, occupation, lifestyle etc, are closely related to the individual and also have a strong influence on his purchasing. Transformations undergone by the individual, such as becoming a Father, or other impacts that may influence the way he lives, also changes his perception over a certain product; it is possible that during a particular period his desire changes; also the fact of having a job that allows him greater purchasing power may change his decision or make him rethink the purchase decision, or even the current economic situation, whether good or bad may define future forecasts to the acquisition of new products etc (Secco, Oliveira \& Amorim, 2014).

It is also important to highlight the values that the individual acquire along his lifetime, that is, highly personal and subjective decisions, which must be rigorously evaluated by the manager in order to prepare for inconsistencies, for instance, that, if well administrated, can be decisive for sustaining a good relationship and conquering the consumer (Hoppe et al., 2012; Yamashita \& Gouvêa, 2007).

\subsection{Profile of The Consumer of Natural Products}

Thanks to the increase in production levels allowed by advancements that have been taking place on the global scenario, concerns with health and environment are becoming something of extreme importance for those who seek to maintain and preserve it, and, in a certain way, to those who indirectly affects it, as it is the case with companies that, being aware of its polluting or aggressive actions towards the environment, are looking for ways to get increasingly close to healthier methods for the environment (Borges \& Tashibana, 2005).

The stiff competition caused by the advancements generated by liberalization and integration of markets (globalization), has, in a certain way, forced members of the food 
INDEPENDENT JOURNAL OF MANAGEMENT \& PRODUCTION (IJM\&P)

http://www.ijmp.jor.br

v. 12, n. 4, May-June 2021

ISSN: 2236-269X

DOI: 10.14807/ijmp.v12i4.1358

production industry, as mentioned above, to adopt more severe policies regarding their productive process, aiming to improve society's quality of life by means of supplying healthier nutrition, free of chemical inputs that have harmful effects for environment and health. Thus, following this trend, even at higher costs, organic, light or diet products are conquering its' space on the market (Perosa et al, 2012).

The consumer of natural products seeks to satisfy his need in the best possible way, often not searching for a product in itself, but rather a quality of life that may come with that product, that is its characteristics of wanting to preserve the environment, owning and influencing sustainable lifestyle, reducing high levels of pollution to the environment etc. means that he does not stick too much to the product, but to what it brings as a benefit for the environment (Gomes, 2009).

With this, one could say that there are several kinds of consumers of natural products based on their choices, because different types of products are capable of bringing messages about the importance of the environment, that is, the profile of the consumer of natural products is closely related to the message brought by that which he buys (Barbosa et al., 2011).

Besides all that aspects, another demand of the consumers of natural products is based on the outside of the food, in other words his purchase decision is also supported by the appreciation of how the food looks, if it exhibit any defects or not, if they are within the expiry date, if they are well conserved and other technical features of the product that will be hereafter associated to the service's quality of the company that offers it, as the face of the product may often reflect the face of the organization (Filho \& Silva, 2012).

Another aspect that can be observed in the profile of the consumer of natural products is the search for healthier products. Technological evolution has brought new means of production for the most various types of business, including agriculture, for example. With this, the use of pesticides or other agrochemical inputs that "artificialize” organic products has been very often employed by the ease they offer, however cases and more cases of problems caused by the irresponsible use of them emerges and this influences even further the creation of the profile of the consumer of natural products as that one who avoids any kind of product which doesn't have a purpose in the life of environment and that have ingredients which threatens health (Lima et al., 2011).

Therefore, more and more features are emerging to define a standard profile of the natural consumer. Another characteristic, based on the previous paragraph, shows the level of 
DOI: 10.14807/ijmp.v12i4.1358

these consumers, that is, they are people who have a high critical and defined sense about the environmental issue, whether with high levels of scholarship or not, these consumers know what they want, are determined and willing to offer a change that will be beneficial for everyone (Lima et al., 2011).

Figure 1 shows some of the main features observed on consumers of natural products on behalf of their purchase process:

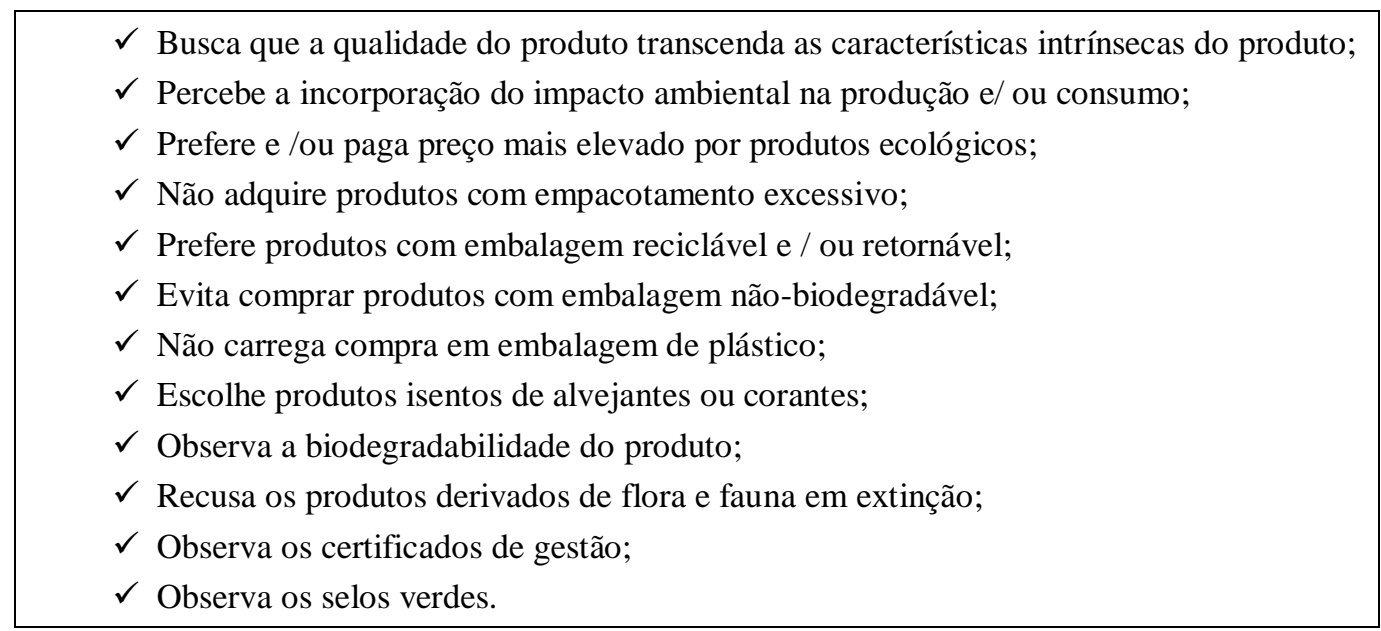

Figure 1: Main features of the consumer of natural products Source: elaborated by the authors from Elkington, Hailes e Makower (1990)

Once more, consumer's concern with the environment issue is revealed here. The presence of sustainable features supports the maintenance of environmental education that must be encouraged in face of the displayed scenarios.

\subsection{Market of Natural Products in Brazil}

In line with what has been already discussed, that society increasing its concern with the environment every day, therefore, with health, on behalf of some rather agressive economic activities, which has had a positive impact on the improvement of productive processes, forcing Brazilian and international organizations to adopt social and environmental policies, sustainable marketing, including the offer of natural products (organic).

Brazil is revealing itself as a rich consumer for this kind of market. Thanks to the growing of the "Fit" concept, these products are gaining even more space inside supermarkets, shopping malls etc., as they promote health and well-being, attracting mainly professional or amateur practitioners of physical activities, who are one of the main consumers of this market of products. In the past, the practice of having a diet based on healthy or natural products was 
INDEPENDENT JOURNAL OF MANAGEMENT \& PRODUCTION (IJM\&P)

http://www.ijmp.jor.br

v. 12, n. 4, May-June 2021

ISSN: 2236-269X

DOI: $10.14807 /$ ijmp.v12i4.1358

more related to people with greater acquisitive power, thanks to the handling and caring that the production of this kind of food required to maintain its quality, increasing its value. However with the growing awareness of companies to healthy and natural food becoming a search to a big part of population, a great opportunity of business creation emerged, consequently jobs and income.

Therefore, the first ones to seize better management of the product will benefit the most, since these are products that depend on time, handling and innovation. With that in sight and the strong pressures exerted by society on all productive processes, some Brazilian states, mirroring England and the whole European Union, prohibited practices of animal testing on cosmetic industries, as well as reduced the extraction of inputs in the Amazon, adopting sustainable methods as species cultivation (domestication), and, for those that could not, educational programs were developed aiming to reduce aggressiveness of extraction process (Souza \& Barata, 2018). Figure 2 shows the guiding principles of green chemistry:

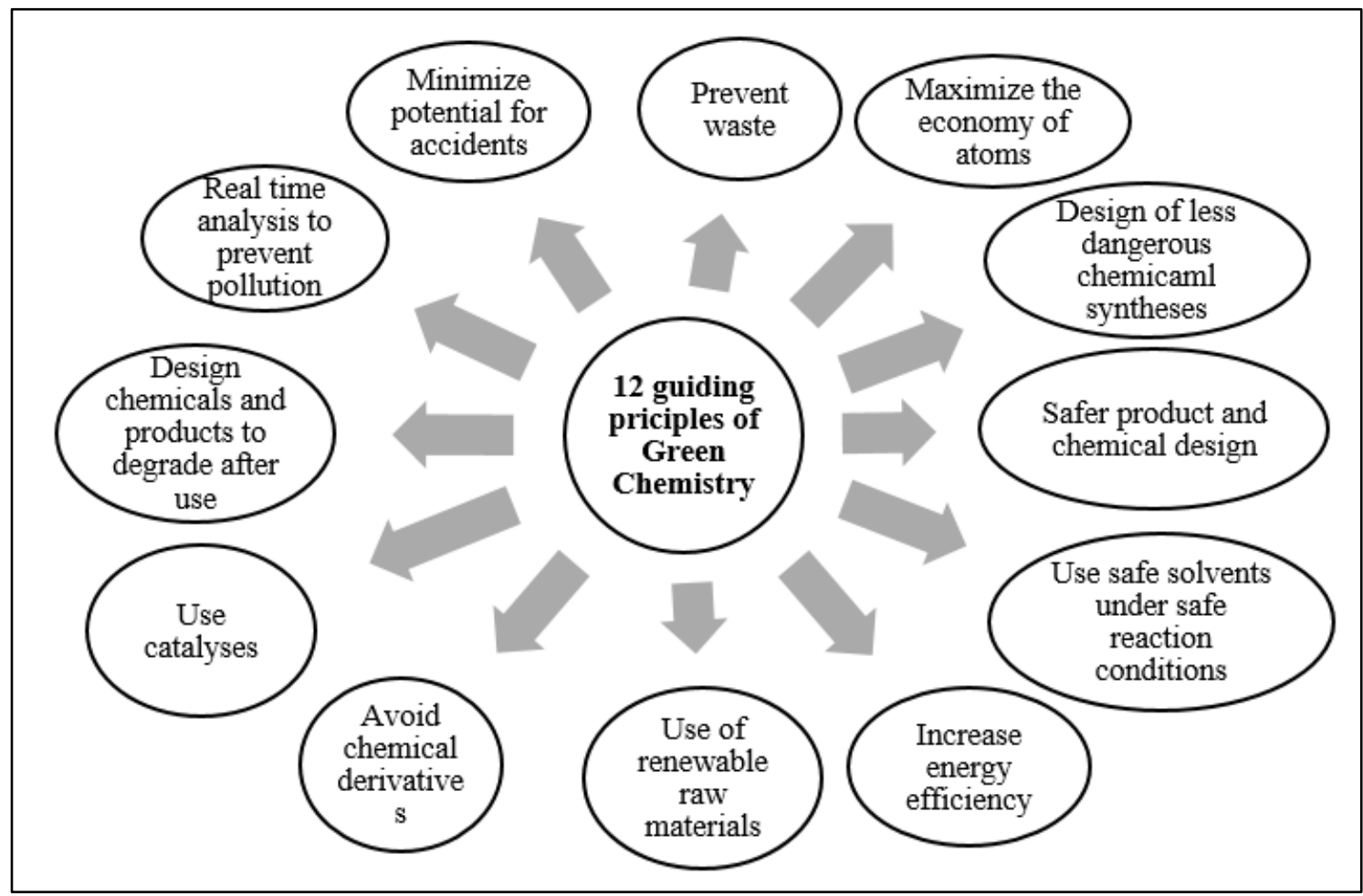

Figure 2: The 12 Principles of Green Chemistry

Source: adapted by the authors from Gomes et al (2018)

It is of common knowledge that Brazil is one of the biggest consumers of cosmetics, resting clear its capacity of requiring more inputs from biodiversity, with positive and negative impacts on the preservation of natural goods and a commerce based on ethical principles. Corroborating what was previously discussed, that is that the idea of a healthier world must be embraced, the manufacturers are beginning to be challenged to develop of green products 
DOI: 10.14807/ijmp.v12i4.1358

without compromising activity, guaranteeing the perpetuation of endangered species and/or reduction of impacts due to not using chemicals in the extraction process. An example of this are cosmetics naturally processed and free of agrochemicals, paraben and sulfate (Gomes et al., 2018).

\section{METHODOLOGY}

The current study is of a qualitative nature, searching to understand and interpret specific behaviors, in this case the green consumer's behavior, using bibliographic research found on Google Scholas, Scielo and Periódico Capes plattforms. Keywords employed in the search were "Consumer's behavior”, "marketing”, "natural products”. Thus, 65 articles were analyzed, of which only 50 were used to the construction of the theoretical framework. The research is of a descriptive nature, in which the object is studied so that its features may be appreciated, as a whole or in its parts, without the interference of the researcher. In relation to the approach way, the research qualifies as qualitative due to the detailing and construction of argumentation of ideas for a better understanding of the theme (Godoy, 1995; Mozzato \& Grzybovski, 2011; Silva, Gobbi \& Simão, 2005).

\section{ANALYSIS AND DISCUSSION OF RESULTS}

This Research has found that is necessary that entrepreneurs of natural products sector to known the factors that affect consumer behavior and different consumer's conceptions, seeking to understand the surroundings in which client is integrated, his wishes and needs, as well as all the transformations on the market and in the world.

This way, the research has detailed that the main issue that the consumer of natural products takes into account when buying is the organization's commitment regarding its client's needs and its environmental organization. In other words, he remains vigilant to a range of aspects, from the hygiene o the place to the compliance of to environmental laws and company's acknowledgement of environmental and health issues around the world. With this, several sets of characteristics will influence consumer's purchase process of natural products, as well as the 12 principles established in figure 2: consumers who are aware of laws, those who will check conditions of food preservation, those who will contribute more actively with the organization, those who will be attentive to everything etc.

In this context, the relevance of knowledge of consumer behavior stands out for the success of an organization. The investment in marketing and researches helps companies to dedicate themselves even more to attract and retain customers not only in its field of activity, 
DOI: 10.14807/ijmp.v12i4.1358

but also consumers of other products and/or services, conquering and retaining fidelity of new clients.

Therefore, one way to develop assertive strategies is through adoption of Circular Economy's concepts regarding organizational processes of conception, production and sales of products and services (Sousa et al., 2019).

The factors that affect consumer behavior have encouraged organizations to seek customers loyalty. As a result, the consumer behavior has been contemplated as a theme in the development of business strategies in face of new markets and consumers, as clients with a green consumer profile have higher standards of general exigency in relation to the many factors involved in purchase process, what renders organizations that attend them much more prepared to thrive in face of competing companies (Carvalho \& Ribeiro, 2019).

\section{CLOSING REMARKS}

For all the discussion exposed in this research, it is evident that companies should be aware that knowing consumer's needs and answering them adequately bring numerous advantages to an organization, such as gaining client loyalty and attracting other niches of consumers since it will get a broader view of the quality of the organization in meeting his needs.

With this, this work reveals the importance of the theme for organizations and shows that the purchase behavior of the consumer of natural products is not based only on their personality, but also in personal, cultural, emotional, psychological factor, as well as environmental issues, therefore the entrepreneur must know the scenario and the market in which the company is integrated in order to analyze the most adequate marketing strategies to the target audience, environmental legislation, processes etc., in order to strengthen the ties between company and consumer.

This way, the information and inferences contained in this research can contribute to organizations that sell natural products define theirs mission, values, vision and marketing strategies, besides rendering possible the creation of business strategies that will address the aspects with greater influence on the consumer when he is deciding on the product he wishes to acquire. Therefore, the research approaches the characteristics of the consumer of natural products and the factors that influences the process of purchase, providing strategic advantages of market positioning and in the creation of strategic models that can attract more and more customers, in addition to seeking to retain them. 


\section{INDEPENDENT JOURNAL OF MANAGEMENT \& PRODUCTION (IJM\&P) \\ http://www.ijmp.jor.br \\ v. 12, n. 4, May-June 2021}

ISSN: 2236-269X

DOI: $10.14807 /$ ijmp.v12i4.1358

Therefore, one of the main features of the behavior of the consumer of natural products is the concern with the environmental issue, the concern with environmental treatment in a more sustainable and less aggressive way. In face of this context, it is notorious that the environmental issue is of utter importance for the scope of organizations, since the impacts caused by mankind to the environment are so catastrophic that cannot go unnoticed, therefore the recommendation for future work is of a more meticulous and detailed evaluation of the relevance of environmental impacts to the consumer in the process of purchase of natural products in order to deepen even more environmental issues that concern both companies and consumers.

\section{REFERENCES}

Aquino, F. M. (2007). Comportamento do consumidor: fatores que influenciam na aquisição de títulos de capitalização. Porto Alegre, RS: Universidade Federal do Rio Grande do Sul.

Barbosa, S. C. et al. (2011). Perfil do consumidor e oscilações de preços de produtos agroecológicos. Pesquisa Agropecuária Tropical. 41(4), 602-609. [Data de consulta: 18 de novembro de 2017]. Disponível em: http://www.redalyc.org/articulo.oa?id=253020131010

Basta, D. (2015). Fundamentos de marketing. Editora FGV.

Borges, W. K., \& Tashibana, F. H. (2005). A evolução da preocupação ambiental e seus reflexos no ambiente dos negócios: uma abordagem histórica. XXV ENGEP - Porto Alegre, RS, Brasil, 29 out a 01 de nov.

Caro, A. (2010). Comportamento do Consumidor e a Compra online: uma análise multicultural. Universidade de São Paulo, São Paulo- SP.

Caro, A. (2005). Fatores críticos do comportamento do consumidor online um estudo exploratório. Faculdade de Economia, Administração e Contabilidade, São Paulo.

Carvalho, K. Y. M., \& Ribeiro, R. E. M. (2019). Inovação em Marketing: percepção de valor na ótica do cliente. (pp. 102-110).. In: Piauí Cases. / Rhubens Ewald Moura Ribeiro , Luis Henrique dos Santos Silva Sousa, Cícero Tadeu Tavares Duarte (Organizadores).. $1^{\text {a }}$ Edição. Teresina: Kindle Direct Publishing, 2019. 197 p. ISBN: 9781705887646

Cobra, M., \& Brezzo, R. (2010). O Novo Marketing. Rio de Janeiro: Elsevier.

Correa, L. P. (2012). O Comportamento do Consumidor de Moda ao Longo das Décadas. Universidade Católica de Pelotas. Rio Grande do Sul.

Dorneles, V. R. et al. (2015). Atitudes, emoções e comportamento de compra dos consumidores dos produtos de luxo. ENCONTRO NACIONAL DE ENGENHARIA DE PRODUÇÃO, Fortaleza - CE.

Elkington, J., Hailes, J., \& Makower, J. (1990). The Green Consumer. New York: Penguin Books.

Figueiredo, C. L. (2012). Motivação no trabalho à luz da teoria de Maslow: o caso de uma clínica médica em campina grande - PB. Campina Grande, PB: UNIVERSIDADE ESTADUAL DA PARAÍBA. 
Filho, D. O. L., \& Silva, F. Q. (2012). Percepção Do Consumidor Sobre Produtos Orgânicos. REMark: Revista Brasileira de Marketing; São Paulo, 11(1), 29.

Freire, C. P. S., Lima, M. V. S., \& Leite, B. da C. (2009). Marketing de relacionamento e sua influência na conquista e manutenção de clientes. Revista Eletrônica de Administração, 08(15).

Godoy, A. S. (1995). Introdução à pesquisa qualitativa e suas possibilidades. Revista de administração de empresas, São Paulo- Brasil, 35(2), 57-63.

Gomes, A. N. (2009). O novo consumidor de produtos naturais: Consumindo conceitos muito mais do que produtos. ESPM, São Paulo - SP, Junho.

Gomes, M., \& Kury, G. (2013). A Evolução do Marketing para o Marketing 3.0: O Marketing de Causa. Fortaleza, CE: UFC.

Gomes, R. N. et al. (2018). Desenvolvimento da química verde no cenário industrial brasileiro.

Hoppe, A. et al. (2012). Comportamento do consumidor de produtos orgânicos: uma aplicação da teoria do comportamento planejado. BASE - Revista de Administração e Contabilidade da Unisinos, p.: 176, abril/junho, Rio Grande do Sul.

Kotler, P., \& Keller, K. L. (2012). Administração de Marketing. $14^{\circ}$ edição. São Paulo: Pearson.

Larentis, F. (2012). Comportamento do Consumidor. Curitiba, PR: IESDE.

Lazzari, F. et al. (2012). Estereótipo negativo do país de origem e intenções e percepções do consumidor: o efeito moderador das ações de marketing. BASE - Revista de Administração e Contabilidade da Unisinos. Rio Grande do Sul.

Lima, P. A. L. et al. (2011). Perfil do consumidor de produtos orgânicos na cidade de são joaquim da barra/SP. Nucleus, 8(1).

Malhotra, N. K. (2012). Pesquisa de marketing: uma orientação aplicada. Bookman Editora. Matteil, D., Machado, M., \& Oliveira, P. A. (2006). Comportamento do consumidor: fatores que influenciam no processo de decisão de compra dos consumidores finais. Maringá Management: Revista de Ciências Empresariais, 3(2), 27-37, jul./dez. Maringá, PR.

Medeiros, J. F., \& Cruz, C. M. L. (2006). Comportamento do consumidor: fatores que influenciam na decisão de compra dos consumidores. Teoria e Evidência Econômica, Passo Fundo, 14(Especial).

Rossini, G. B. (2016). Perfil do consumidor de varejo especializado em produtos naturais: valores e atitudes. Departamento de Ciências Administrativas, Escola de Administração, UFRGS, Porto Alegre - RS.

Mozzato, A. R., \&Grzybovski, D. (2011). Análise de Conteúdo como Técnica de Análise de Dados Qualitativos no Campo da Administração: Potencial e Desafios. RAC, Curitiba - P.R., 15(4), 731-747, Jul./Ago.

Natel, M. C., Tarcia, R. M. L., \& Sigulem, D. (2013). A aprendizagem humana: cada pessoa com seu estilo. Revista Psicopedagógica, 30(92), São Paulo.

Oliveira, I. C., Neto, A. L. C. M. (2016). Comportamento do consumidor: a influência das mídias sociais na decisão de compra de produtos gamers. Revista de Pós-Graduação

Faculdade Cidade Verde, 2(1), Maringá-PR. 
Oliveira, P. H., Gonçalves, C. A., \& Paula, E. A. M. (2011). Diretrizes para a condução de uma atividade de inteligência competitiva: uma análise preliminar. R. Intelig. Compet., São Paulo, 1(3), 257-272, out./dez.

Ono, A. T. et al. (2014). O processo de decisão de compra por meio da web: um estudo de campo aplicando o CHIC. Educ. Matem. Pesq., São Paulo, 16(3), 745-772.

Pena, B. S., Coutinho, F. G. A., \& Pépece, O. M. C. (2012). Eu e o bebê estamos com desejo! Os significados culturais do consumo de alimentos por grávidas. Rev. Ciênc. Admin., Fortaleza, 18(1), 390-418, jan./jun.

Perosa, J. M. Y. et al. (2012). Perfil do consumidor de frutas em cidades do interior do estado de São Paulo - SP. Rev. Bras. Frutic. [online]. 34(4), 1084-1090. ISSN 0100-2945. https://doi.org/10.1590/S0100-29452012000400015.

Peter, J. P., \& Olson, J. C. (2010). Comportamento do Consumidor e Estratégia de Marketing. Ed. 8, Porto Alegre.

Pinheiro, R. M. et al. (2011). Comportamento do Consumidor. $1^{\circ}$ Edição, Rio de Janeiro: Editora FGV.

Portela, C. B. M. (2011). O Marketing e o Comportamento do Consumidor. PUC, São Paulo.

Porto, R. B., \& Oliveira-Castro, J. M. (2013). Preditores da correspondência intençãocompra: experimento natural com reforço das marcas. Psicologia: Teoria e Pesquisa, Brasília, 29(1), 61-70, jan./mar.

Ramos, C. A. C. et al. (2013). Classe C, ascensão e alguns reflexos mercado consumidor. Revista de Gestão \& Tecnologia - ReGeT, 1(1), dez., São Paulo, 2013.

Secco, C. F. C., Oliveira, E. M., \& Amorim, R. M. C. (2014). Comportamento do consumidor: fatores que determinam o processo de compra no mercado varejista em Palmas-TO. Revista Científica do ITPAC, Araguaína, 7(3-4), Julho.

Silva, C. R., Gobbi , B. C., \& Simão, A. A. (2005). O uso da análise de conteúdo como uma ferramenta para a pesquisa qualitativa: descrição e aplicação do método. Organ. rurais agroind., Lavras - M.G., 7(1), 70-81.

Souza, A. S. S., \& Barata, A. J. T. S. S. (2018). Consumo consciente: ativismo, ética e a indústria de cosméticos verdes. In: $10^{\circ}$ Salão Internacional de Ensino, Pesquisa e Extensão SIEPE, 2018, Santana do Livramento. Anais do 10o. SIEPE | 3. Bagé: UNIPAMPA, 10, 1-1.

Sousa, G. B., Silva, J. M. A. S., Santos, J. S. A., \& Ribeiro, R. E. M. (2019). Economia Circular: fluxo de resíduos de uma empresa alimentícia em Teresina-PI. (pp. 70-78). In: Piauí Cases. / Rhubens Ewald Moura Ribeiro , Luis Henrique dos Santos Silva Sousa, Cícero Tadeu Tavares Duarte (Organizadores).. $1^{\text {a }}$ Edição. Teresina: Kindle Direct Publishing, 197 p. ISBN: 9781705887646

Teixeira, J. C. I. (2010). Fatores que influenciam o comportamento do consumidor. Rio de Janeiro.

Torres , F. M. C. (2007). A influência da percepção no comportamento de compra. Centro Universitário De Belo Horizonte - Uni-Bh, Belo Horizonte, 26 de maio.

Vilain, J. S. B., \& Pereira, M. F. (2013). O impacto do status no planejamento financeiro pessoal: estudo de caso com os advogados de florianópolis, santa catarina. Revista Gestão e Planejamento, Salvador, 14(3), 470-488, set./dez. 
Vilas Boas, L. H. B. (2005). Comportamento do consumidor de produtos orgânicos: uma análise na perspectiva da teoria da cadeia de meios e fins. LAVRAS, MG: UFLA.

Watanabe, E. A. M. (2014). A influência da cultura no comportamento do consumidor de supermercados. 2014. 135 f., il. Tese (Doutorado em Administração).—Universidade de Brasília, Brasília.

Yamashita, S. S., \& Gouvêa, M. A. (2007). Marketing de relacionamento: importância e implicações no mercado consumidor. Revista de Administração Mackenzie, 8(4), 103-124.

Zuppani, T. S., \& Lima, M. V. V. (2014). Emoções e regulação emocional no comportamento do consumidor: algumas perspectivas. RAIMED - Revista de Administração IMED, Rio Grande do Sul. 